\section{The British military-industrial complex in history: the importance of political economy}

\section{David Edgerton}

$\mathrm{P}$

robably the single most important tradition of enquiry into the British militaryindustrial complex has been the political-economic one. Political science, strategic studies, and the like have been surprisingly silent on the subject, as have historians, including military historians. Economic historians have dominated the small number of scholars who have paid it any attention. Indeed, rethinking the history of the British military-industrial complex had involved a recovery and a critical engagement with the earlier works of political economists, and a recognition too of the importance of political economic thinking in British strategy. ${ }^{1}$ The important tacit assumptions that underlay the political-economic approach need challenging if we are to have an adequate picture of the history of the production of the means of destruction.

Much of what interwar political economists wrote on defense and warlike industries has been forgotten.

This article recalls their contributions.

To speak of a British militaryindustrial complex (MIC), except during and of the very recent past, is to indulge in a major historical impertinence. For, if one took accounts of British arms production that dominated the history books, not only did the complex not exist (except prior to 1914), but could not have done so. The interwar years, it used to be taken for granted, saw the arms industry reduced to practically nothing by disarmament. Rearmament in the 1930 s was tardy, and the miracles of war production came from "war socialism" led by the Minister of Labor, Ernest Bevin, brought in from the trade union movement by Winston Churchill in May 1940. After the war, it is generally agreed, there was too much spending on armaments, but there was nothing as dangerous as an MIC - the problem was oldfashioned imperialist attitudes, great power delusions, and subservience to the United States. The effects on the British economy of over-investment in arms were held to be highly negative.

Elsewhere I give an alternative account of the history of the British militaryindustrial-scientific complex between 1920 and 1970, and of the relevant old and new literatures on this. ${ }^{2}$ Here, drawing on this work, I want to sketch out the main points of interest, particular in relation to political-economic thinking. Much of what interwar political economists wrote on defense and warlike industries has been forgotten. Yet political economy was into the 1940s one of the main languages used to discuss matters of defense and international relations in Britain. From the 1970 s a left political economy was one of the main critical languages used, although the official discourse had little political economy in it.

Political economy and warlike spending in the interwar years

Political economists noted that interwar British warlike expenditure was high by historical standards. For example, that great Liberal party plan of 1928 , Britain's Industrial Future (the Yellow Book) noted that:

There is no automatic standard of reasonableness in the connection [arms expenditure]; but we may find comparatively firm ground if we regard our expenditure on defence as an insurance premium incurred to enable us to live our own lives in peace and consider what rate of premium we have paid for this privilege in the past. During the last quarter of the nineteenth century we were in no imminent danger of war ... Our defence expenditure was $£ 25 \mathrm{~m}$ - a premium of 2 per cent. In $1913 \ldots$ the premium had jumped to $3 \frac{1}{2} 2$ percent. Today it is still 3 per cent, though we see no reason for regarding this country as in greater peril than in the last quarter of the nineteenth century. ${ }^{3}$

In 1934, F.W. Hirst, a former editor of The Economist, upholding the great traditions of nineteenth century liberalism, wrote that "Despite the unparalleled burdens of growing taxation, the British Government, like other Governments, though participating in a Disarmament Conference, is increasing or maintaining enormous armaments for land, sea and air." Hirst, quoting from the main speech in favor of the Oxford Union's scandalous 1933 resolution (that the house would not fight for King and Country) argued with irony that:

The War, according to Mr. Lloyd George, was to make England "a land fit for heroes to live in"; but it had produced a mass of unemployment previously unknown. It had also been described as "a war to end war", with the result that "we are now spending forty millions more than in 1913 in preparations for the next war".

Correction for inflation was not an immediate reflex, but it would have got rid of most of the increase Hirst mentioned.

Yet taking prices into account also affected accounts of what happened in the early 1930 s, but in an opposite direction. For, while prices inflated during and after the Great War, they deflated in the 1920s and early 1930s. Noting this, H.N. Brailsford, another veteran political economist concerned with war, but one closely linked to the left, observed in 1934 that Britain was spending more in real terms on defense in the early 1930 s than it had been in the late $1920 \mathrm{~s}^{6}{ }^{6}$ The interwar critics were certainly right to correct for deflation, just as they should have corrected for the earlier 
inflation, thus avoiding needless alarm about supposedly rising defense expenditure. A political-economic conception of warfare was influential not just in highlighting the raw level of defense expenditure, but the significance of the arms industry. There was much more criticism, in this literature, and more generally, of the armaments industry than of Britain's armed forces. Indeed the greatest campaign waged by the interwar peace movement was against the private arms industry and the international arms trade. The campaign succeeded in establishing a Royal Commission on the Private Manufacture of and Trading in Arms - it sat from 1935 into 1936 - which generated a great deal of evidence on the industry. A leading campaigner, and another political economist, Philip Noel-Baker, followed up his own evidence with a book, The Private Manufacture of Armaments, which like most of the evidence, drew much of its material from the pre-war era, focused on the arms trade (in the sense of traffic), the degree of monopoly of the arms firms, the links among these firms and the military through directorships, and the international nature of the firms. The campaigners, like their pre-war predecessors called for the nationalization of the arms firms, and the arms trade.

There were definite limits to this activist agenda, particularly with respect to the British arms firms. Although a good deal of telling detail can be gleaned on the contemporary British arms industry and arms lobbies, the campaigners did not produce an adequate overall description of the interwar British military-industrial complex on the world stage, or in British politics. Only the Communist Party consistently, although never comprehensively, pointed to the strength and connections of the British arms industry, and to the size of the British arms trade. It started its evidence with the claim that the United Kingdom was "the largest world exporter of armaments" and was therefore "the main pillar of the world arms traffic, the evils of which have been universally condemned."7 This argument was based on League of Nations data for the years 1928-1932, which covered armaments in the narrow sense, excluding warships and military aircraft.

Sir Maurice Hankey, secretary of the British Cabinet and of the Committee of Imperial Defense, went to great lengths to challenge this conclusion and to play down British strength. By looking at later years, and only at exports outside imperial territories, he showed that in 1934 Britain had 11.1 percent of the trade, well behind France and Czechoslovakia (which had the key arms plants of the former AustroHungarian empire). However, by the same criteria, Hankey handily omitted to mention, Britain was the largest exporter in 1929, 1930, and 1931, with shares ranging from 19 percent to 28.1 percent. For the years 1932 and 1933 Britain was below France, but between them they shared almost half the world market. ${ }^{8}$

The communists were right. There is no doubt that Britain was a major arms exporter, whose main competitor was France. ${ }^{9}$ If a broader definition of armaments had been adopted the British and French shares would probably have been larger. For the export of warships and aircraft were indeed very important, especially for Britain, and indeed France. In the late 1920s and early 1930 s British arms exports in this wider sense were worth around $£ 6 \mathrm{~m}$. About $£ 2 \mathrm{~m}$ of this was military aircraft, engines, and spares. ${ }^{10}$ Until the mid-1930s Britain was probably the largest exporter of aircraft of them all. As well as confirming the strength of the arms export trade, modern research suggests that far from being non-existent, the British arms industry employed at the very least 84,000 workers before rearmament in the public and private sectors, with the largest private firm being Vickers, employing around 20,000 workers making armaments from guns to aircraft. ${ }^{1}$

\section{Post-war silence}

Critical analysis of the British arms industry, never especially strong, abruptly ended in the late 1930s, and was not to revive until the 1970s. Particularly curious is that the strong peace movement of the late 1950 s and early 1960 s did not generate an account of the British military-industrial complex. One reason was the virtual disappearance in Britain of the political economic approach to these questions. In academic international relations, political economy, along with "idealism," was left behind. In critical commentary on defense policy the political-economic language became rarer, not least because nuclear weapons in the view of many instituted a new era of warfare in which political economy was irrelevant. Philip Noel-Baker and John Strachey, veterans of the political-economic approach of the 1930s, and both middle-ranking ministers in post-war Labor governments, both wrote books on defense which in the late 1950 s and early 1960 s, which focused on nuclear weapons. ${ }^{12}$ This is not to say that political economy was not used, only that it was marginal, restricted to figures like Barbara Ward of The Economist ${ }^{13}$ and elements of the far left, notably the Trotskyite International Socialists with their theory of the permanent arms economy. Another example was the New Left argument for positive neutralism, anti-nuclearism, and planned trade with the emerging non-aligned economies. But these were exceptions. The radical opposition to defense policy in the years 1957-1963 was informed above all by "moral imperialism."14

In the 1970 s and 1980 s there was a great revival in socialist political economic writing on Britain, the British state, and on issues of war and peace. The 1970s also saw a resurgence of British marxist writing on military expenditure and capitalism, a literature that went beyond the theory of the permanent arms economy, much published in the Cambridge Journal of Economics. As applied to Britain this literature had at its core the observation that Britain spent considerably more on defense as a proportion of GDP than did most continental European countries and the argument that this defense expenditure negatively affected the economy. Particular attention was paid to the supposed costs of high levels of defense R\&D. The 1980 s also saw the emergence of mostly declinist political economies of twentieth century Britain, which made great play of the weakness of the British state in matters industrial. The key idea was that twentieth century Britain lacked and had lacked a "developmental state." A common argument was the commitment to a strong alliance with the United 
States, and high defense spending, especially overseas, contributed to a lack of development at home, and hence to the British economic decline. ${ }^{15}$

The nature of the political-economic account

The account given by British intellectuals of British history and of Britain at war has been a profoundly civilian one: civilian forces led to success in war, shaped strategy, deprived the forces of weapons. Of course there are important exceptions, notably in the field of military history, and yet the dominant approach is profoundly civilian. In these civilian accounts, the military are taken out of these stories: they are seen, at best, as old-fashioned and resistant to the necessary modern means of waging war. The political economic approach is particularly prone to seeing in industry, technology, and science - all viewed as profoundly civilian - the main determinants of success in war. Again, one needs to register the existence of exceptions, but also the dominant trend.

Within this framework, only some militarily relevant technologies were called "armaments." As in the discussion of the arms trade in the interwar years, it was not uncommon to exclude aircraft and warships from the definition of armaments. Aeroplanes and ships were seen as essentially a civilian transport technology rather than as a weapon of war, produced by essentially civilian industries. When civilian, modern industry comes into contact with the conservative armed forces the result was seen as being a distorted technology, and a decline in civilian economic vigor. The argument was present in the $1930 \mathrm{~s}$, but a particular interesting version was put forward by Mary Kaldor. ${ }^{16}$ She saw technical innovation coming from the civil side, specifically competitive private industry, but she put the military themselves in the picture, but only as conservative consumers. The military wanted, she argued, more powerful existing types of weapons, not to shift to new ones. The result was a "baroque arsenal," a phrase which neatly invoked Kaldor's central idea. This was that the over-elaboration of existing technologies of war leads to rapidly diminishing returns, indeed to negative returns. "Baroque" also captures a historical conjuncture which replicates the implicit model of an ancient military and modern technology. Peace time military technology had a grotesque, distorted quality. Moreover, in Kaldor's view, the industry producing baroque weapons acted as a drag on the development of the economy as a whole. In war, according to Kaldor, crisis conditions result in the overthrow of military conservatism and the adoption of radical new technologies and ways of fighting war, of civilian origin. These new forms themselves become baroque in the ensuing peace.

These views need revision at a number of different levels. One particularly common argument of the political economists was that British military R\&D crowded out civilian $R \& D$ and that this was a major cause of poor British growth post-war. The argument, although influential, does not stack up. Britain had exceptionally high levels of civilian industrial $\mathrm{R} \& \mathrm{D}$, and, at national level we should not expect high levels of growth to follow from high R\&D (or vice versa). In the post-war years the military-industrial-complex was at the heart of a powerful British developmental state The supply ministries were a great stimulus to British industrial development. Investment in warlike production did positively affect some parts of British manufacturing industry, during and after the Second World War. The concept of war potential lead to the development of many new industries in Britain after the war that would not otherwise have existed. The great state technological programs surely also stimulated R\&D in other sectors, helping promote a culture celebrating R\&D, looking for technological leapfrogs, and more generally promoting technological and nationalistic considerations over economic ones. From the point of view of advocates of a "developmental state" all this could have been seen in a positive light. Instead, students of industrial and technological policy contrived to ignore these major efforts of the British state.

Contrary to the traditional view, military production has been highly specialized, rather than a mere application of civilian industry. Take the case of warshipbuilding. The key sites were not the shipyards and marine engineering works, but highly specialized makers of armored plates, guns, and mountings. The aircraft industry, so often seen as civilian but applied to defense, was more military than warshipbuilding: it was from the first a national industry maintained for national military purposes. The specialist nature of the industry helps explain an often concealed feature of the arms industry. In the Second World War relatively little civilian industry was turned over to the production of arms, although the implication is usually that this was where arms production came from. The key processes were the building of new specialized capacity, and the extension of the existing armament firms. There were new entrants on the electrical and electronic side, but none of significance in other branches. The war greatly strengthened the existing military-industrial complex, as would be expected, but this is implicitly denied in most existing accounts.

We need, I believe, to recognize the military origins of military technology rather than succumbing to traditions of argumentation which insist by repetition on the essentially civilian nature of technology and science. And indeed, many important civil industries previously taken to be essentially civilian ones applied to war are better described as military technologies applied to peace, aviation being a key example. We should cease to think of aviation and nuclear power, and radio, and much else besides, as civil technologies temporarily given over to war-fighting, but rather see that they are cases of fundamentally military and state technologies which would probably have not existed were it not for the existence of competing nationstates. Far from threatening to supersede the nation-state, as many liberals alleged, these technologies were products of the anarchic world they supposedly threatened. Of course, the civilian and military dimensions are thoroughly intertwined, not leas because, as in the British case, the same organization was often asked with promoting both - the official line insisted on the unity of the military and the civilian. The main examples in the British case were the Atomic Energy Authority into the early 1970s, 
and the various incarnations of ministries responsible for aviation, which were until 1970 concerned with military and civil aviation: the Air Ministry to 1940; the Ministry of Aircraft Production, 1940-1946; the Ministry of Supply, 1946-1959; the Ministry of Aviation, 1959-1967, and the Ministry of Technology, 1967-1970.

The importance of the public sector

One important but little discussed part of the British military-industrial complex has been in the public sector. Armed forces have long employed civilian workers directly to produce weapons of war. For much of the twentieth century the public sector was the major producer of small arms, as well as an important producer of explosives and propellants, heavy guns, and ships' hulls. Indeed proponents of the nationalization of the arms sector rarely gave enough attention to the existing state industries. At the same time the military had their own major research, development, and testing facilities. The public and private sectors had a complex and often fraught relationship, for they were both in cooperation and competition with each other. Yet some important changes can be outlined. The relative importance of the private sector grew considerably from the end of the nineteenth century, with the state leaving important areas (like gun mountings and aircraft) to it. Yet one must be careful since many new equipments came of the state sector, including aircraft for a period. From the $1930 \mathrm{~s}$ the importance of the public sector increased in both old and new technologies of war. New devices like radar, jet engines, and explosives like RDX, as well as many new guns were developed and designed in the public sector. During the war, and into the post-war years the importance of the state sector increased, with the development of new and entirely state-sector branches like the military-nuclear industry. Indeed many of the important privatizations of the 1980 s were of industries that had never been in the private sector, like Royal Ordnance and parts of the atomic complex. Yet in other cases the story is rather different. The great private armorers of the post-war years were the aircraft and electronic contractors. They remained in private ownership into the 1970s, when through particular crises (Rolls-Royce and Ferranti) they came into public ownership, or were nationalized as part of the nationalization of the aircraft and shipbuilding industries in 1977. The great exception was the electrical contractor GEC, which emerged as the largest private arms firm. Yet the nationalizations of the 1970s were not to last - British Shipbuilders and British Aerospace were among the first enterprises privatized by the Thatcher government. By the end of the Thatcher era, for the first time in history the private sector utterly dominated arms supply.

\section{Conclusion}

Understanding the nature of the arms production process and military technologies has been strongly affected by very particular understandings of the place of the military in modernity. We need to understand those assumptions if we are to make sense of one of the most important yet neglected aspects of economic life of the twentieth century.

Notes

David Edgerton is Hans Rausing Professor at Imperial College London. He may be reached atd.edgerton@imperial.ac.uk.

1. Peden (1979, 2007); Strachan, (1985, pp. 447-61); Offer (1989); French (1990); and Edgerton $(1991,2005)$ are some representative works.

2. Edgerton (1991, 2005).

3. Liberal Industrial Enquiry (1928, p. 428), quoted in Skidelsky (1992, p. 269). Skidelsky argues that it is plausible to attribute the point to Keynes.

4. Hirst (1934, p. 96).

5. Hirst (1934, pp. 97-98).

6. Brailsford ( 1934, p. 177)

7. Memorandum submitted on behalf of the Communist Party of Great Britain, Minutes of Evidence, p. 71.

8. First Memorandum by Sir Maurice Hankey, Appendix E, Table C, Minutes of Evidence. Anthony Sampson makes the point that Britain was the largest exporter of arms in the world before 1932, based on this data, noting the omission of empire. He does not, however, point to the fact that these figures exclude warships and aircraft. Sampson (1978, p. 74 ).

9. Harkavy (1975); Sampson (1978); Krause (1992).

10. Noel-Baker Memorandum, Minutes of Evidence, p. 280.

11. Edgerton (2005).

12. Noel-Baker (1960); Strachey (1962).

13. Ward (1951) is an exception. She worked for The Economist and later became very well known as a pioneer environmentalist. 
14. Taylor (1988, pp. 305-307).

15. Kaldor, et al. (1979); Aaronovitch (1981); Smith and Smith (1983), Chalmers (1985); Fine and Harris (1985).

16. Kaldor (1982).

\section{References}

Aaronovitch, S. et al. 1981. The Political Economy of British Capitalism: A Marxist Analysis. Maidenhead: McGraw Hill.

Anderson, David G. 1994. "British Rearmament and the 'Merchants of Death': The 1935-6 Royal Commission on the Private Manufacture of and Trading in Arms." Journal of Contemporary History Vol. 29, pp. 5-37.

Brailsford, H.N. 1934. Property or Peace? London: Gollancz.

Chalmers, M. 1985. Paying for Defence: Military Spending and the British Decline. London: Pluto.

Edgerton, David. 1991a. "Liberal Militarism and the British State." New Left Review No. 185 (Jan.-Feb.), pp. 138-169.

Edgerton, David. 1991b. England and the Aeroplane: An Essay on a Militant and Technological Nation. London: Macmillan.

Edgerton, David. 2005. Warfare State: Britain, 1920-1970. Cambridge: Cambridge University Press.

Fine, Ben and Laurence Harris. 1985. The Peculiarities of the British Economy. London: Lawrence and Wishart.

French, David. 1990. The British Way in Warfare, 1688-2000. London: Unwin Hyman.

Harkavy, Robert. 1975. The Arms Trade and International Systems. Cambridge, MA: Ballinger.

Hirst, Francis W. 1934. The Consequences of the War to Great Britain. London: Oxford University Press.

Kaldor, Mary. 1982. The Baroque Arsenal. London: Deutsch.

Kaldor, Mary, Dan Smith, and Steve Vines, eds. 1979. Democratic Socialism and the Cost of Defence. London: Croom Helm.

Krause, Keith. 1992. Arms and the State: Patterns of Military Production and Trade. Cambridge: Cambridge University Press.

Liberal Industrial Enquiry. 1928. Britain's Industrial Future. London: Ernest Benn.

Noel-Baker, Philip. 1960. The Arms Race. London: Calder.

Offer, Avner. 1989. The First World War: An Agrarian Interpretation. Oxford: Clarendon Press.

Peden, George. 1979. British Rearmament and the Treasury. Edinburgh: Edinburgh University Press.
Peden, George. 2007. Arms, Economics, and British Strategy. Cambridge: Cambridge University Press.

Sampson, Anthony. 1978. Arms Bazaar. London: Coronet.

Skidelsky, Robert. 1992. John Maynard Keynes. Vol. II: The Economist as Saviour, 1920-1937. London: Macmillan.

Smith, Dan and Ron Smith. 1983. The Economics of Militarism. London: Pluto. Strachey, John. 1962. On the Prevention of War. London: Macmillan.

Taylor, Robert. 1988. Against the Bomb: The British Peace Movement, 1958-1965. Oxford: Clarendon Press.

Ward, Barbara. 1951. Policy for the West. Harmondsworth: Penguin. 